\title{
HERITABILITY AND GENETIC ADVANCE OF YIELD AND YIELD RELATED TRAITS IN WINTER FEED BARLEY VARIETIES
}

\author{
N. Dyulgerov*, B. Dyulgerova \\ Institute of Agriculture - Karnobat, Agricultural Academy, Karnobat, Bulgaria
}

\begin{abstract}
A field experiment was conducted at the Institute of Agriculture - Karnobat, Southeastern Bulgaria in three growing seasons. Twenty barley varieties were laid out in a complete block design with 4 replications. Variability, heritability and genetic advance for yield-related traits and grain yield were studied. There were significant differences among varieties for all studied traits including grain yield. Heritability in broad sense ranged from $10.10 \%$ for grain yield to $94.60 \%$ for spike length. High heritability estimates and genetic advance as percent of mean was computed for spike length and 1000 grain weight. Besides, genotypic coefficient of variance and phenotypic coefficient of variance had low differences for these characters. Therefore, these traits could be easily improved by selection. Grain yields of the check varieties Veslets and Izgrev were $5.27 \mathrm{t} / \mathrm{ha}$ and $5.09 \mathrm{t} / \mathrm{ha}$, respectively. The varieties that performed better than the checks for grain yield were PA86-49-95 (6.43 t/ha), Bojin (6.01 t/ha), and Express $(5.90 \mathrm{t} / \mathrm{ha})$. Hence, using these varieties in the breeding program of winter feed barley could lead to the improvement of grain yield.
\end{abstract}

Kay words: heritability, genetic advance, winter feed barley, grain yield, yield-related traits

\section{INTRODUCTION}

In the world, barley ranks fourth among cereal crops in terms of production after maize, rice, and wheat. Barley is the third most important cereal in Bulgaria but occupies a much smaller acreage than either wheat or maize. Barley grain is the main raw material of the brewing (1). There is renewed interest in using barley as a food associated with the possibility of reducing the risk of Type II diabetes, heart disease, and obesity when barley grain is a component of healthy diets (2). The most common use of barley worldwide and in Bulgaria is for feed (3).

Despite the varied end-uses, high stresstolerance, and adaptability of this crop, barley production and acreage are declining each year in Bulgaria as well in all worlds. In many areas, barley is replaced by other more profitable crops. One of the possibilities to stop or reverse this process is the development of barley varieties with improved grain yield.

\footnotetext{
*Correspondence to: Nikolay Dyulgerov, Institute of Agriculture - Karnobat, Agricultural Academy, Bulgaria, e-mail: ndyulgerov@abv.bg
}

The information for available genetic variation and the inheritance of yield-related traits are crucial for determining the breeding strategy for barley grain yield improvement. Heritability estimation gives information about the degree of genetic control in particular traits and genetic advance is an important parameter to determine the expected selection response.

Yield improvement of barley depends on the presence of genetic variation for yield-related traits. In most modern barley breeding programs, usually, a limited number of advanced lines are intensively used. This leads to a significant loss of genetic diversity (4-6). Therefore, continued yield gain depends on the introgression of novel alleles from wild relatives, exotic germplasm and elite germplasm from other breeding programs. The development of varieties with a wider genetic base may be beneficial in enhancing the yield under various agro-climatic conditions (7) and improved disease resistance (8).

The aim of the present study was to evaluate the variability, heritability and genetic advance for yield-related traits and grain yield of 20 
winter barley varieties and to identify the highyielding varieties for inclusion in the breeding program of feed barley at the Institute of Agriculture - Karnobat.

\section{MATERIALS AND METHODS}

The experiment was carried out at the Institute of Agriculture - Karnobat, Bulgaria. The experimental site is characterized by the transitional continental climate with an average annual rainfall of $549 \mathrm{~mm}$ and a long-term average annual air temperature of $11.4^{\circ} \mathrm{C}$. The weather conditions for the experimental period 2015/2016 - 2017/2018 for Karnobat are presented in Table 1 . The soil of the experimental field is slightly acid leached Chernozem. The field management was according to accepted for the region practices. The field traits were organized on plots of 10 $\mathrm{m}^{2}$ in a complete block design with 4 replications.

Table 1. Origin of 20 varieties of winter feed barley used in the present study

\begin{tabular}{ll}
\hline Origin & Variety \\
\hline Bulgaria & Veslets, Izgrev, Bojin \\
France & Atlas, Barberosse, Maniton, Gerlach, Rebelle \\
Germany & Bronhild, Express, Krimhild, Frances, Sigra \\
Russia & Mihailo, Radical \\
USA & PA8649-95, GA-Lutrell \\
China & Rombohedral \\
Sweden & Hampus \\
Switzerland & Riniker \\
\hline
\end{tabular}

The experiment included 20 six-rowed winter barley varieties with different geographical origin (Table 2). Twenty spikes were sampled from each variety in each replication and spike length $(\mathrm{cm})$, number of spike lets per spike, number of grains per spike, grain weight per spike (g), were measured. On plot basis were determined: number of spikes per $\mathrm{m}^{2}, 1000-$ grain weight $(\mathrm{g})$, and grain yield ( $\mathrm{t} / \mathrm{ha})$.

Tables 2. Average air temperatures and sums of precipitation during the experimental period for Karnobat

\begin{tabular}{lllllllll}
\hline \multirow{2}{*}{ Month } & \multicolumn{2}{l}{$2015 / 2016$} & \multicolumn{2}{l}{$2016 / 2017$} & \multicolumn{2}{l}{$2017 / 2018$} & $\mathrm{LT}$ & \\
\cline { 2 - 8 } & $\mathrm{T},{ }^{\circ} \mathrm{C}$ & $\mathrm{P}, \mathrm{mm}$ & $\mathrm{T},{ }^{\circ} \mathrm{C}$ & $\mathrm{P}, \mathrm{mm}$ & $\mathrm{T},{ }^{\circ} \mathrm{C}$ & $\mathrm{P}, \mathrm{mm}$ & $\mathrm{T},{ }^{\circ} \mathrm{C}$ & $\mathrm{P}, \mathrm{mm}$ \\
\hline October & 12.3 & 41.8 & 12.1 & 67.0 & 12.5 & 270.0 & 12.5 & 44.3 \\
November & 10.5 & 45.6 & 7.5 & 36.9 & 8.4 & 38.8 & 7.1 & 53.7 \\
December & 3.8 & 0.2 & 0.6 & 5.7 & 5.2 & 93.1 & 2.6 & 51.2 \\
January & 0.7 & 133.2 & -2.5 & 28.9 & 2.5 & 49.0 & 0.6 & 36.5 \\
February & 7.9 & 43.7 & 3.7 & 32.9 & 3.5 & 81.1 & 2.2 & 35.8 \\
March & 8.2 & 56.1 & 8.3 & 24.1 & 6.4 & 121.2 & 5.3 & 34.1 \\
April & 13.7 & 55.2 & 10 & 35.4 & 19.3 & 6.0 & 10.5 & 45.3 \\
May & 15.7 & 130.8 & 16.1 & 36.6 & 17.9 & 68.6 & 15.6 & 58.5 \\
June & 21.6 & 42.9 & 21.7 & 55.0 & 20.8 & 98.6 & 19.6 & 65.2 \\
July & 23.7 & 4.9 & 23.4 & 40.7 & 23.1 & 134.0 & 22.0 & 49.9 \\
August & 23.6 & 28.1 & 23.9 & 21.3 & 23.6 & 0 & 21.6 & 33.7 \\
September & 19.0 & 10.4 & 19.9 & 32.8 & 18.7 & 29.7 & 17.6 & 40.8 \\
T, ${ }^{\circ} \mathrm{C}$ & 13.4 & - & 12.1 & - & 13.5 & - & 11.4 & - \\
P, mm & - & 592.9 & - & 417.3 & & 990.1 & & 549.0 \\
\hline T - average air temperature; P - sum of precipitation; LT - long-term average air temperature and sum of \\
precipitation;
\end{tabular}

Analysis of variance (ANOVA) and Least Significant Difference (LSD) between varieties was computed by SPSS 16.00 for Windows 16.0 (SPSS Inc., 2007). Phenotypic $\left(\sigma^{2} \mathrm{ph}\right)$ and genotypic $\left(\sigma^{2} \mathrm{~g}\right)$ variances were obtained from the analysis of variance (ANOVA) table (9).
Heritability in broad sense $\left(\mathrm{h}^{2}\right)$ was calculated as (10):

$\mathrm{h}^{2}=(\sigma 2 \mathrm{~g} / \sigma 2 \mathrm{ph}) \cdot 100$

where: $\sigma^{2} \mathrm{~g}$ - genotypic variance and $\sigma^{2} \mathrm{ph}$ phenotypic variance. 
Phenotypic Coefficient of Variation (PCV) and Genotypic Coefficient of Variation (GCV) were estimated as (11):

$\operatorname{GCV}(\%)=\frac{\sqrt{\sigma^{2} \mathrm{~g}}}{\mathrm{x}} \cdot 100$

$\operatorname{PCV}(\%)=\frac{\sqrt{\sigma^{2} \mathbf{p h}}}{\mathrm{x}} \cdot 100$

where: $\sigma^{2} g$ - genotypic variance, $\sigma^{2} p h$ phenotypic variance, $\mathrm{X}$ - mean.

Genetic advance (GA) was calculated by the following formula (11):

$\mathrm{GA}=\mathrm{k} . \sigma \mathrm{ph} . \mathrm{h}^{2}$ where: $\mathrm{k}=2.06$ (constant for 5\% selection intensity), $\sigma \mathrm{ph}$ - square root of phenotypic variance, $\mathrm{h}^{2}$ - heritability (broad sense).

Genetic advance as \% of mean was calculated as:

\section{$\mathrm{GAM}=(\mathrm{GA} / \mathrm{X}) \cdot 100$}

where: GA- genetic advance and $\mathrm{X}$ - mean.

\section{RESULTS}

The results from the analysis of variance showed significant $(\mathrm{p}<0.05)$ differences among varieties for grain yield and studied yield-related traits (Table 3). The influence of growing year and variety by year interaction on the variation of all studied traits was also significant.

Table 3. Mean squares for grain yield and yield-related traits of 20 winter feed barley varieties

\begin{tabular}{llllllll}
\hline $\begin{array}{l}\text { Source of } \\
\text { variation }\end{array}$ & NS & SL & NSS & NGS & GWS & TGW & GY \\
\hline G & $81024.56^{*}$ & $25.61^{*}$ & $191.19^{*}$ & $248.53^{*}$ & $0.95^{*}$ & $314.57^{*}$ & $5.20^{*}$ \\
Y & $65194.55^{*}$ & $0.61^{*}$ & $164.02^{*}$ & $124.77^{*}$ & $9.38^{*}$ & $1601.27^{*}$ & $17.69^{*}$ \\
GxY & $43794.75^{*}$ & $1.38^{*}$ & $40.68^{*}$ & $57.16^{*}$ & $0.54^{*}$ & $34.21^{*}$ & $4.68^{*}$ \\
Error & 126.63 & 0.08 & 2.11 & 1.81 & 0.03 & 0.60 & 0.08 \\
\hline
\end{tabular}

$\mathrm{G}$ - genotype; Y - year; GxY - genotype x year interaction; * significance at $\mathrm{p} \leq 0.05$; NS - number of spikes per $\mathrm{m}^{2}$; SL - spike length; NS - number of spikelets per spike; NGS - number of grains per spike; GWS - grain weight per spike; TGW - 1000-grain weight; GY - grain yield;

The mean performances of the varieties are presented in Table 4. The number of spikes per $\mathrm{m} 2$ ranged from 585 to 866 . Two varieties of Bojin and PA8649-95 had a significantly higher number of spikes per $\mathrm{m} 2$ compared to control varieties. The spike length varied from $4.20 \mathrm{~cm}$ for GA-Lutrell to $8.94 \mathrm{~cm}$ for Riniker. The significantly higher number of spikelets in spike compared to both control varieties had Atlas, Bronhild, and Mihailo. The most of the studied varieties (Bojin, Atlas, Barberosses, Bronhild, Maniton, Mihailo, PA8649-95, Rebelle, Krimhild, Riniker and Sigra) had a higher number of grains in spike than control variety Veslets. The grain weight per spike varied from $2.01 \mathrm{~g}$ (Frances) to $2.97 \mathrm{~g}$ (Riniker). Only variety Riniker showed a significantly higher weight of grains per spike than the control variety with the highest grain weight per spike Veslets (2.69 g). Control varieties are differed significantly for the 1000grain weight $(47.70 \mathrm{~g}$ for Veslets and $43.02 \mathrm{~g}$ for Izgrev). All studied varieties showed lower 1000-grain weight than Veslets. Grain yields of the check varieties Veslets and Izgrev were $5.27 \mathrm{t} / \mathrm{ha}$ and $5.09 \mathrm{t} / \mathrm{ha}$, respectively. The varieties that had significantly higher grain yield than the check varieties were PA86-4995 (6.43 t/ha), Bojin (6.01 t/ha), and Express (5.90 t/ha).

The genetic parameters of traits under investigation are presented in Table 5. The phenotypic coefficient of variation and genotypic coefficient of variation can be defined as low $(<10 \%)$, moderate $(10-20 \%)$, and high $(>20 \%)$ (12). Based on this classification, the low phenotypic coefficient of variation was found for the traits number of spikelets per spike and the number of grains per spike. The traits with moderate values of phenotypic coefficient of variation were the number of spikes per $\mathrm{m} 2$, grain weight per spike, 1000-grain weight, and grain yield. Spike length was the only trait with a high phenotypic and genotypic coefficient of variation. Number of spikes per $m 2$, number of spikelets per spike, number of grains per spike, grain weight per spike and grain yield had a low genotypic coefficient of variation. A moderate genotypic coefficient of variation was recorded for 1000-grain weight. 
DYULGEROV N., et al.

Table 4. Mean values of grain yield and yield-related traits of 20 winter barley varieties (2015/20162017/2018)

\begin{tabular}{llllllll}
\hline Variety & NS & SL & NSS & NGS & GWS & TGW & GY \\
\hline Veslets & 824 & 7.73 & 69.97 & 57.61 & 2.69 & 47.70 & 5.27 \\
Izgrev & 813 & 7.90 & 71.17 & 57.19 & 2.35 & 43.02 & 5.09 \\
Bojin & 861 & 5.63 & 70.45 & 61.71 & 2.61 & 45.65 & 6.01 \\
Atlas & 621 & 8.24 & 77.45 & 64.51 & 2.84 & 45.29 & 3.94 \\
Barberosses & 743 & 7.41 & 72.42 & 60.75 & 2.18 & 34.31 & 4.79 \\
Bronhild & 585 & 8.41 & 79.58 & 68.01 & 2.28 & 33.29 & 4.25 \\
Express & 786 & 7.57 & 67.32 & 57.46 & 2.52 & 46.83 & 5.90 \\
Frances & 676 & 7.67 & 67.30 & 50.39 & 2.01 & 40.91 & 4.81 \\
GA-Lutrell & 684 & 4.20 & 65.84 & 50.71 & 2.21 & 44.16 & 4.53 \\
Gerlah & 729 & 7.88 & 66.63 & 58.91 & 2.78 & 47.60 & 5.25 \\
Hampus & 719 & 7.72 & 69.57 & 58.30 & 2.47 & 45.11 & 5.27 \\
Maniton & 662 & 8.31 & 68.58 & 62.21 & 2.62 & 46.63 & 4.67 \\
Mihailo & 743 & 5.80 & 75.73 & 66.08 & 2.56 & 36.43 & 5.34 \\
PA8649-95 & 866 & 4.73 & 71.31 & 59.94 & 2.07 & 34.86 & 6.43 \\
Radical & 692 & 5.01 & 66.00 & 59.69 & 2.42 & 40.01 & 5.14 \\
Rebelle & 676 & 7.39 & 69.83 & 60.99 & 2.26 & 37.82 & 3.97 \\
Krimhild & 654 & 7.43 & 70.01 & 62.47 & 2.68 & 43.28 & 4.59 \\
Riniker & 614 & 8.94 & 72.56 & 61.72 & 2.97 & 46.83 & 4.43 \\
Rombohedral & 644 & 4.35 & 64.70 & 56.80 & 2.12 & 36.53 & 4.42 \\
Sigra & 667 & 6.12 & 74.94 & 66.38 & 2.08 & 34.26 & 4.97 \\
LSD & 16.56 & 0.46 & 2.33 & 2.15 & 0.27 & 1.24 & 0.43 \\
\hline
\end{tabular}

$\mathrm{NS}-$ number of spikes per $\mathrm{m}^{2}$; SL - spike length, cm; NS - number of spikelets per spike; NGS - number of grains per spike; GWS - grain weight per spike, g; TGW - 1000-grain weight, g; GY - grain yield, t/ha;

Heritability is classified as high when it has a value higher than $80 \%$, moderate when it ranges between $40-80 \%$ and low when it is less than $40 \%$ (13). Accordingly, spike length and 1000grain weight had high heritability. The traits number of spikes per $\mathrm{m} 2$, number of spikelets per spike, number of grains per spike and grain weight per spike showed moderate heritability. Low heritability was observed for grain yield.

Genetic advance ranged from $0.14 \%$ for grain yield to $77.78 \%$ for number of spikes per $\mathrm{m} 2$, while genetic advance as percent of mean varied from $2.76 \%$ for grain yield to $41.20 \%$ for slike length. Genetic advance as percent of mean is considered as low $<10 \%$, moderate $10-20 \%$, and high $>20 \%$. (12). Accordingly, high genetic advance as percent of mean was found for spike length and 1000-grain weight. Moderate values of genetic advance as percent of mean was estimated for the traits: number of spikes per $\mathrm{m} 2$, number of grains per spike, grain weight per spike. Values of genetic advance as percent of mean were low for grain yield and number of spikelets per spike.

Table 5. Mean $(X)$, phenotypic variance $\left(\sigma^{2} p h\right)$ and genotypic variance $\left(\sigma^{2} g\right)$, heritability in broad sense $\left(h^{2}\right)$, phenotypic coefficient of variation $(P C V)$, genotypic coefficient of variation $(G C V)$, and genetic advance (GA) and genetic advance as percent of mean (GAM)

\begin{tabular}{lllllllll} 
Trait & $\mathrm{X}$ & $\sigma^{2} \mathrm{ph}$ & $\sigma^{2} \mathrm{~g}$ & $\mathrm{~h}^{2}$ & $\mathrm{PCV}$ & GCV & GA & GAM \\
\hline NS & 713 & 3102.48 & 6752.05 & 45.95 & 11.51 & 7.80 & 77.78 & 10.89 \\
SL & 6.92 & 2.02 & 2.13 & 94.60 & 21.14 & 20.56 & 2.85 & 41.20 \\
NSS & 70.57 & 12.54 & 15.93 & 78.73 & 5.66 & 5.02 & 6.47 & 9.17 \\
NGS & 60.09 & 15.95 & 20.71 & 77.00 & 7.57 & 6.65 & 7.22 & 12.01 \\
GWS & 2.44 & 0.03 & 0.08 & 42.98 & 11.53 & 7.56 & 0.25 & 10.21 \\
TGW & 41.52 & 23.36 & 26.21 & 89.13 & 12.33 & 11.64 & 9.40 & 22.64 \\
GY & 4.95 & 0.04 & 0.43 & 10.10 & 13.25 & 4.21 & 0.14 & 2.76 \\
\hline
\end{tabular}

NS - number of spikes per $\mathrm{m}^{2}$; SL - spike length, $\mathrm{cm}$; NS - number of spikelets per spike; NGS - number of grains per spike; GWS - grain weight per spike, g; TGW - 1000-grain weight, g; GY - grain yield, t/ha; 


\section{DISCUSSION}

The development of high-yielding varieties is the main aim of any breeding program. The achievement of this goal depends on the availability of a sufficient amount of genetic variability. Herefore, for crop improvement, the continuous supply of new germplasm as donors of various genes of agronomic interest is needed. In the present investigation, twenty barley varieties with different geographical origins were studied in order to identify genetic resources for inclusion in the feed barley breeding program of the Institute of Agriculture - Karnobat.

The significant differences among barley varieties were found indicated the presence of genetic variability for grain yield and yieldrelated traits in studied plant material. Genotype by year interaction also was significant for all studied traits which usually complicates the selection process. Welu (14) and Sayd et al. (15) also reported significant genotype by environment interaction for yield and yield-related trait in barley.

Information for genetic parameters of yieldrelated traits is required for the planning of efficient plant breeding programs. Greater values of phenotypic coefficient of variation than the values of the genotypic coefficient of variation for grain yield and yield-related traits were found in the present study. A similar relationship between the two coefficients has been reported in other studies of barley (1618).

The large differences between the values of the phenotypic and genotypic coefficients of variation show a considerable influence of the environment on the expression of the phenotype. In the present study, the greater differences between phenotypic and genotypic coefficients of variation were found in grain yield, grain weight per spike, and a number of spikes per $\mathrm{m} 2$. The magnitude of the difference between the phenotypic and genotypic coefficients of variation was low for spike length, spikelets number per spike, and 1000grain weight. This implies that the environmental factors have a relatively low influence on these traits and there is a higher chance of their improvement by phenotype selection. A small difference between phenotypic and genotypic coefficients of variation for 1000-grain weight in barley has been reported previously (19-21).
The difference between the phenotypic and genotypic coefficients of variation was high for spike number per $\mathrm{m} 2$ and grain weight per spike and very high for grain yield. Hence, the environmental factors had a greater influence on the phenotypic expression of the traits which complicate improvement by phenotypebased selection.

Heritability (broad sense) is the ratio of total genetic variance including additive, dominance, and epistatic variance to the phenotypic variance. Low heritability has been the main factor limiting the genetic gain for quantitative traits as grain yield in plant breeding programs. Heritability studies are essential for the planning of effective breeding programs. Results for heritability of different studies differed considerably because the heritability estimates are affected by the genotype and environmental conditions (10). In the present study, grain yield had the lowest heritability of all studied traits. This result is in agreement with the findings of Pržulj and Momcilović (22) and Ahmadi et al. (18). On the contrary, high heritability estimates for grain yield have been reported $(17,23)$. Lower heritability estimate for yield in this study than those reported in other work may be due to contrasting environmental conditions in different growing years and low adaptability of studied barley varieties to Southeastern Bulgarian conditions.

The high heritability for spike length and 1000-grain weight indicates that these traits can be further improved by selection. Nanak et al. (24) and Monteiro et al. (25) also reported high heritability of 1000-grain weight. High heritability indicates that those traits are less affected by the environment in their expression and the selection based on phenotypic performance could be effective.

Selection efficiency is higher for traits that have high heredity combined with high genetic advance (26). Furthermore, high heritability accompaned by a high genetic coefficient of variation also indicates the possibility for an effective selection of genotypes based on the phenotype. In the current study, high heritability estimates and high genetic advance as percent of mean was found for spike length and 1000 grain weight. Spike length and 1000 grain weight had a higher genotypic coefficient of variance that others studied traits. Besides, the genotypic and phenotypic coefficients of 
variance had low differences for these traits. This indicates the possibility of improvement of these traits through the selection. Probably these traits under control of additive genes and phenotypic selection could be effective in early generations (27). Moderate estimates for both heritability and genetic advance as percent of mean was found for a number of spikes per $\mathrm{m}^{2}$, a number of grains per spike and grain weight per spike. Low estimates for heritability and genetic advance as percent of the mean was observed for grain yield. This shows a high influence on the environment and a limited possibility for improvement through direct selection. Akgun (28) reported high heritability coupled with high genetic advance for plant height, spike length, number of spikelets per spike, number of grains per spike, grain weight per spike, and heading time. Ahmadi (18) found the highest heritability and genetic advance for the number of grains per spike.

The results of this investigation showed the possibility to used studied varieties as genetic material to broaden the genetic basis of feed barley breeding program at the Institute of Agriculture - Karnobat. Including the best performing varieties in hybridization with locally adapted varieties could result in improving some yield-related traits as number of spikes per $\mathrm{m}^{2}$, number of grains per spike and grain weight per spike. Varieties PA86-4995, Bojin, and Express which showed significantly higher mean grain yield for 3 growing years compared to control varieties are of particular interest for including in barley breeding program.

\section{CONCLUSION}

Significant differences among varieties of winter feed barley for all studied yield-related traits and grain yield were found. Heritability in broad sense ranged from $10.10 \%$ for grain yield to $94.60 \%$ for spike length. High heritability estimates and genetic advance as percent of mean was computed for spike length and 1000-grain weight. Besides, genotypic coefficient of variance and phenotypic coefficient of variance had low differences for these characters. Therefore, these traits could be easily improved by selection. Grain yields of the check varieties Veslets and Izgrev were $5.27 \mathrm{t} / \mathrm{ha}$ and $5.09 \mathrm{t} / \mathrm{ha}$, respectively. The varieties that performed better than the checks for grain yield were PA86-49-95 (6.43 t/ha), Bojin (6.01 t/ha), and Express (5.90 t/ha). Hence, using those varieties in the breeding program of winter feed barley could lead to the improvement of grain yield.

\section{REFERENCES}

1. Schwarz, P. and Li, Y., Malting and brewing uses of barley. In: Ullrich SE (ed.), Barley: Production, improvement, and uses, Oxford Wiley-Blackwell, UK, pp 478-521, 2010.

2. Newman, R. K. and Newman, C. W., Barley for food and health: Science, technology, and products. John Wiley \& Sons, USA, 2008

3. Blake, T., Blake, V. C., Bowman, J. G. and Abdel-Haleem, H. In: Ullrich SE (ed.), Barley: Production, improvement, and uses, Oxford Wiley-Blackwell, UK, 522-531, 2010.

4. Martin, J. M., Blake, T. K. and Hockett E. A., Diversity among North American spring barley cultivars based on coefficients of parentages. Crop Sci, 31(5):1131-1137.

5. Ferreira, J. R., Pereira, J. F., Turchetto, C., Minella, E., Consoli, L. and Delatorre, C. A., Assessment of genetic diversity in Brazilian barley using SSR markers. Genetics and molecular biology, 39(1):86-96, 2016.

6. Condón, F., Gustus, C., Rasmusson, D. C., and Smith, K. P., Effect of advanced cycle breeding on genetic diversity in barley breeding germplasm. Crop Sci, 48(3):10271036, 2008.

7. Asif, M., Rahman, M. and Zafar, Y., DNA fingerprinting studies of some wheat (Triticum aestivum L.) genotypes using random amplified polymorphic DNA (RAPD) analysis. Pakistan Journal of Botany, 37(2):271-277, 2005.

8. Zhu, Y., Chen, H., Fan, J., Wang, Y., Li, Y., Chen, J., Fan, J. X., Yang, S., Hu, L., Leung, H. and Mew, T. W., Genetic diversity and disease control in rice. Nature, 406(6797):718-722, 2000.

9. Comstock, R. R. and Robinson H. F., Genetic parameters, their estimation and significance. In: Proceedings of 6th International Grassland Congress. State College, PA, USA: Pennsylvania State College, 248-291, 1952.

10.Falconer, D. S. and Mackay T. F. C., Introduction to Quantitative Genetics, Benjamin Cummings, London, UK., 4th Edn., 1996.

11.Singh, R. K. and Chaudhary, B. D., Biometrical Methods in Quantitative 
Analysis. Kalayani Publishers, New Delhi, India, 1985.

12.Deshmukh, S. N., Basu, M. S. and Reddy P. S., Genetic variability, character association and path analysis of quantitative traits in Virginia bunch varieties of ground nut. Indian Journal of Agriculture Science, 56: 816-821, 1986.

13.Singh, B. D., Plant Breeding: Principles and Methods. Kalyani Publishers, New Delhi, India, 6th Edn., 2001.

14.Welu, G., Genotype $\mathrm{X}$ Environment Interaction of Food Barley. Ecoprint: An International Journal of Ecology, 21:41-48, 2014.

15.Sayd, R. M., Amabile, R. F., Faleiro, F. G., Costa, M. C., and Montalvão, A. P. L., Genetic parameters and agronomic characterization of elite barley accessions under irrigation in the Cerrado. Acta Scientiarum. Agronomy, 41, e42630. Epub June $13,2019$. https://dx.doi.org/10.4025/actasciagron.v41 i1.42630

16.Jalata, Z., Ayana, A. and Zeleke H., Variability, Heritability and Genetic Advance for Some Yield and Yield Related Traits in Ethiopian Barley (Hordeum vulgare L.) Landraces and Crosses. International Journal of Plant Breeding and Genetics, 5:44-52, 2011.

17.Al-Tabbal, J. A. and Al-Fraihat, A. H., Genetic variation, heritability, phenotypic and genotypic correlation studies for yield and yield components in promising barley genotypes. Journal of Agricultural Science, 4(3):193-210, 2012.

18.Ahmadi, J., Vaezi, B. and PourAboughadareh, A., Analysis of variability, heritability, and interrelationships among grain yield and related characters in barley advanced lines. Genetika, 48(1):73-85, 2016.

19.Addisu, A. and Shumet, T., Variability, heritability and genetic advance for some yield and yield related traits in barley (Hordeum vulgare L.) landraces in Ethiopia. International Journal of Plant Breeding and Genetics, 9(2), 68-76, 2015.

20.Dinsa, T., Mekbib, F. and Letta, T., Genetic Variability, Heritability and Genetic Advance of Yield and Yield Related Traits of Food Barley (Hordeum vulgare L.) Genotypes in Mid Rift Valley of Ethiopia. Adv Crop Sci Tech, 6(401):299310, 2018.

21.Ebadi-Segherloo, A., Mohammadi, S. A., Sadeghzadeh, B. and Kamrani, M., Study of Heritability and Genetic Advance of Agronomic Traits in Barley (Hordeum Vulgare L.) and Graphic Analysis of Trait Relations by Biplot. Jordan Journal of Agricultural Sciences, 405(3691):1-12, 2016.

22.Pržulj, N. and Momcilović, V., Characteristics of malting barley in southeast Europe. I. Spring barley. In: Ceccarelli S, Grando S (eds), Proceedings of the 10th International Barley Genetics Symposium. Alexandria, Egypt 5-10 Apr 2008, pp 484-494, 2008.

23.Hailu, A., Alamerew, S., Nigussie, M. and Assefa, E. Genetic variability, heritability and genetic advance for yield and yield related traits in barley (Hordeum vulgare L.) germplasm. World Journal of Agricultural Sciences, 12(1), 36-44, 2016.

24.Nanak, C., Vishwakarma, S. R., Verma, O. P. and Kumar, M., Worth of genetic parameters to sort out new elite barley lines over heterogeneous environments. Barley genetics newsletter, 38:10-13, 2008.

25.Monteiro, V. A., Amabile, R. F., Spehar, C. R., Faleiro, F. G., Vieira, E. A., Peixoto, J. R., Ribeiro Junior, W. Q. and Leite Montalvão, A. P., Genetic parameters and morpho-agronomic characterization of barley in the Brazilian Savannah. Journal of the Institute of Brewing, 124(2), 121-131, 2018.

26.Johnson, H. W., Robinson, H. F. and Comstock R. E., Estimates of genetic and environmental variability in soybeans. Agron. J., 47:314-318, 1955.

27.Ali, S., Shah, S.M.A., Hassnain, A., Shah, Z. and Munir, I., Genotypic variation for yield and morphological traits in wheat. Sarhad J. Agric., 23: 943-946, 2007.

28.Akgun N., Genetic Variability and Correlation Studies in Yield and Yield Related Characters of Barley (Hordeum vulgare L.) Genotypes. Selcuk J Agr Food Sci, 30(2):88-95, 2016. 